\title{
Canine Silica Urolithiasis in Mexico, Associated with the Concentration of Dissolved Silica in Tap Water
}

\author{
Claudia Iveth Mendoza-López $\mathbb{D}^{1},{ }^{1}$ Javier Del-Angel-Caraza $\mathbb{D}{ }^{1}{ }^{1}$ \\ María Alejandra Aké-Chiñas $\mathbb{D},{ }^{1}$ Israel Alejandro Quijano-Hernández $\left(\mathbb{D},{ }^{1}\right.$ \\ Jody P. Lulich $\mathbb{D},^{2}$ and María Vicenta Esteller-Alberich $\mathbb{D}^{3}$ \\ ${ }^{1}$ Hospital Veterinario para Pequeñas Especies de la Facultad de Medicina Veterinaria y Zootecnia, \\ Universidad Autónoma del Estado de México, Toluca, Mexico \\ ${ }^{2}$ Department of Veterinary Clinical Sciences, College of Veterinary Medicine, University of Minnesota, Saint Paul, \\ Minnesota, USA \\ ${ }^{3}$ Instituto Interamericano de Tecnología y Ciencias del Agua-IITCA, Universidad Autónoma del Estado de México, \\ Toluca, Mexico \\ Correspondence should be addressed to Javier Del-Angel-Caraza; dlangel@uaemex.mx
}

Received 13 December 2020; Accepted 25 June 2021; Published 5 July 2021

Academic Editor: Yoshiaki Hikasa

Copyright (c) 2021 Claudia Iveth Mendoza-López et al. This is an open access article distributed under the Creative Commons Attribution License, which permits unrestricted use, distribution, and reproduction in any medium, provided the original work is properly cited.

\begin{abstract}
Silica urolithiasis is infrequent in dogs, but in Mexico represents $12.9 \%$. Our hypothesis is the consumption of high amounts of silicates in the diet, especially that dissolved in tap water. The objective of this study was to determine the concentrations of silica in the tap water in different geographical areas and their relationship with cases of silicate urolithiasis in dogs. From 179 cases of silicate urolithiasis, 98.9\% were from dogs within a geographic area called the Trans-Mexican Volcanic Belt, which represents a cross shaft to the center of the country. Silica concentrations in tap water ranged between 3 and $76 \mathrm{mg} / \mathrm{L}$, with a range of 27 to $76 \mathrm{mg} / \mathrm{L}$, a mean of $49.9 \pm 12 \mathrm{mg} / \mathrm{L}$ within the Trans-Mexican Volcanic Belt, and a concentration from 3 to $30 \mathrm{mg} / \mathrm{L}$, with a mean of $16.4 \pm 7 \mathrm{mg} / \mathrm{L}$ outside this area; these were significantly different $(p<0.001)$. These findings demonstrate that there is a geographic risk factor for silicate urolithiasis in urolith-forming dogs, related to the consumption of tap water with a high concentration of silica. Further studies are necessary to identify this same pathophysiological association in other species.
\end{abstract}

\section{Introduction}

Silica urolithiasis $(\mathrm{SiU})$ is infrequent in dogs. In a global epidemiological study, $\mathrm{SiU}$ represented 0.69 to $0.74 \%$ of the samples analyzed in the reference laboratory [1]. Similar frequencies have been reported in local studies conducted in countries such as Brazil, United Kingdom, Spain, Portugal, and Canada [2-5]. In France, Hungary, and Ireland, it was not reported [6-8]. However, it was $6.7 \%$ in the United States [9], 8\% in Switzerland [10], and 9.2-13.3\% in Mexico [11-13]; the frequencies have been considerably higher.

It has been suggested that $\mathrm{SiU}$ is related to the urinary supersaturation of silicates $\left(\mathrm{SiO}_{4}\right)^{4-}(\mathrm{SiO})$, derived from the consumption and intestinal absorption of different silicates present in the diet. It is common in cattle and sheep from the Great Plains of North America and in some areas of Australia, where it is related to the feeding of these species, namely, the consumption of forage grasses with a high $\mathrm{SiO}$ content [14]. In dogs, it has been associated with the consumption of low-quality pet food in which vegetable ingredients, e.g., corn gluten, rice husks, wheat husk, beet pulp, and barley, are added as a source of protein or soluble fiber that may have high $\mathrm{SiO}$ content [15]. In a report of native dogs in Kenya, this pathology was hypothesized in association with the consumption of corn and water with a concentration of silica (Si) of $20-30 \mathrm{mg} / \mathrm{dl}$ [16].

In humans, $\mathrm{SiU}$ clinical cases related to the chronic use of antacids containing magnesium trisilicate have been 
reported, so this is considered of medicinal origin [17]. However, a clinical case of a 10-month-old baby with SiU, without drug use, was associated with the consumption of water with a high concentration of Si [18]. Recently, it has been related to a possible geographical-cultural risk factor, as reported in West Africa, where SiU is associated with pica. Pica is a widespread practice in several population groups that consume clay as a condiment, which acts as a source of high $\mathrm{SiO}$ content in the diet [19].

In Mexico, $\mathrm{SiU}$ has been reported in populations of dogs that live in cities located within the geographical area called the Trans-Mexican Volcanic Belt (TMVB) [11-13], the largest Neogene volcanic arc in North America that encompasses $160,000 \mathrm{~km}^{2}$ with a length of almost $1,000 \mathrm{~km}$ in central Mexico. It is characterized as being a large mass of volcanic rocks composed of a high SiO content [20]. Although specific medications and diets have been associated with $\mathrm{SiU}$ in humans, we have not observed these risk factors in dogs forming $\mathrm{SiU}$. We hypothesize that the drinking tap water from the aquifers in the TMVB in Mexico contains a high concentration of $\mathrm{Si}$ and is a geographic risk factor for the formation of uroliths in dogs [11-13].

The objective of this study was to determine the concentration of $\mathrm{Si}$ in the tap water in different regions of Mexico (populations located within and outside of the TMVB) and its relationship to SiU in the TMVB in dogs.

\section{Materials and Methods}

During the period from January 2016 to July 2018, we measured the concentration of $\mathrm{Si}$ in drinking water samples taken directly from the tap in different states of Mexico. We also analyzed the urolith database from the period 2005 to 2018 of the Urolith Analysis Laboratory of the Veterinary Hospital for Small Species of the Faculty of Veterinary Medicine and Zootechnics of the Autonomous University of the State of Mexico (UAL-HVPE-UAEM). Urolith samples were referred by veterinarians from different states of the country for analysis, accompanied by a registration form containing general and clinical information and the geographic location of clinical cases in the country. We count the registry data of the states where the SiU cases occurred; once located, the origin of the $\mathrm{SiU}$ cases and the water samples were grouped into two geographical areas: the central region, within the TMVB (ITMVB), and the region outside the TMVB (OTMVB), which, in turn, was divided into two areas (north and south).

2.1. Water Sample Collection and Preservation. The water samples were collected by opportunity sampling from the 32 states of Mexico; samples were taken directly from the tap in a $250 \mathrm{~mL}$ plastic bottle and preserved by refrigeration at $4^{\circ} \mathrm{C}$ until analysis [21].

2.2. Analysis of $\mathrm{Si}$ in Water. The concentration of $\mathrm{Si}$ in the water was determined by the method of colorimetry, with a system of reagents using the silicomolybdate method (Code 3687-SC; SMART2 colorimeter, LaMotte Company, MD,
USA), and details on sample preparation methods were described in [21]. Briefly, in a glass tube containing the sample to be analyzed ( $10 \mathrm{ml}$ of water), hydrochloric acid was added and mixed. Subsequently, ammonium molybdate and potassium hydroxide were added. The tube was then covered, mixed, and left to stand for 5 minutes. At the end of the 5-minute period, oxalic acid was added, and then, the tube was covered, mixed, and placed inside the colorimeter to scan the sample. Si forms a complex with ammonium molybdate in an acidic solution and produces a yellow color proportional to the amount of Si present. The Si concentration measurements were expressed in $\mathrm{mg} / \mathrm{L}$ [21].

2.3. Statistical Analysis. The obtained data were stored in a database using the Excel program and analyzed with GraphPad Prism 6.0 (https://www.graphpad.com CA, USA). To determine the risk factors according to the geographic location of the stone-forming dogs, the control group was selected from the database of urolithiasis cases analyzed at the UAL-HVPE-UAEM; this included cases of stoneforming dogs of other types of uroliths, in the same period of time as the cases with a diagnosis of $\mathrm{SiU}$; the $X i^{2}, \mathrm{OR}$, and $95 \%$ confidence interval were determined. The mean, range, and standard deviation for the values of the concentrations of $\mathrm{Si}$ in the water were calculated. Differences in the concentration means between the geographical regions were determined using an ANOVA. Differences were considered significant when $p<0.05$.

\section{Results}

A total of 1,383 uroliths from dogs were analyzed. Prevalence of each type of uroliths were struvite $n=611(44.2 \%)$; calcium oxalate $n=372$ (26.9\%); silica $n=179(12.9 \%)$; purines $n=57$ (4.1\%); cystine $n=17$ (1.2\%); calcium phosphate $n=13(0.9 \%)$; and mixtures of minerals in mixed uroliths $n=105(7.6 \%)$ and compounds $n=29(2.1 \%)$. Therefore, silicate uroliths represented $12.9 \%(n=179)$ and OU $87.1 \%$ $(n=1,204)$.

On the basis of the region of origin of patients who formed uroliths, $1184(85.6 \%)$ cases were ITMVB, whereas 199 (14.4\%) cases were OTMVB. Of the 179 cases of SiU, 177 (98.9\%) were found in the states located ITMVB (Table 1); only two cases $(1 \%)$ were in two states in the north region of the country located OTMVB (Table 2). Dogs from ITMVB had a significantly higher risk $(\mathrm{OR}=17.31 \quad 95 \%$ $\mathrm{CI}=4.261-70.35 ; p<0.05)$ of forming silica uroliths.

A total of 168 drinking tap water samples were analyzed, taken directly from the tap, corresponding to 32 states in Mexico. Si concentrations in drinking water ranged between 3 and $76 \mathrm{mg} / \mathrm{L}$ (Figure 1). Table 3 shows the number of samples analyzed for each state, as well as the mean concentration of $\mathrm{Si}$ in the tap water.

The highest concentrations of $\mathrm{Si}$ in the water occurred in the ITMVB region (Figure 2), with a range of 27 to $76 \mathrm{mg} / \mathrm{L}$ and a mean of $49.9 \pm 12 \mathrm{mg} / \mathrm{L}$. For the case of the OTMVB region, the Si concentration ranged from 3 to $30 \mathrm{mg} / \mathrm{L}$, with a 
TABle 1: Proportion of SiU in states within and outside the Trans-Mexican Volcanic Belt.

\begin{tabular}{|c|c|c|c|c|c|}
\hline States ITMVB & $\begin{array}{c}n \\
\text { SiU/OU }\end{array}$ & $\%$ & States OTMVB & $\begin{array}{c}n \\
\text { SiU/OU }\end{array}$ & $\%$ \\
\hline Aguascalientes & $6 / 9$ & 66.6 & Chihuahua & $1 / 40$ & 2.5 \\
\hline Colima & $7 / 58$ & 12.0 & Nuevo Leon & $1 / 54$ & 1.8 \\
\hline Guanajuato & $10 / 37$ & 27.0 & Other states & $0 / 103$ & 0 \\
\hline Hidalgo & $7 / 9$ & 77.7 & & & \\
\hline Jalisco & $18 / 177$ & 10.1 & & & \\
\hline Mexico City & $58 / 463$ & 12.5 & & & \\
\hline Mexico state & $53 / 139$ & 38.1 & & & \\
\hline Michoacan & $7 / 47$ & 14.9 & & & \\
\hline Morelos & $4 / 6$ & 66.6 & & & \\
\hline Nayarit & $1 / 7$ & 14.2 & & & \\
\hline Puebla & $3 / 28$ & 10.7 & & & \\
\hline Queretaro & $3 / 10$ & 30 & & & \\
\hline Other states & $0 / 17$ & 0 & & & \\
\hline
\end{tabular}

ITMVB: within the Trans-Mexican Volcanic Belt; OTMVB: outside of the Trans-Mexican Volcanic Belt; SiU: silica urolithiasis cases; OU: other urolithiasis cases.

TABLE 2: Distribution of silica urolithiasis cases in different geographical areas of Mexico.

\begin{tabular}{lccc}
\hline & $\mathrm{SiU}$ & $\mathrm{OU}$ & Total \\
& $n(\%)$ & $n(\%)$ & $n(\%)$ \\
\hline ITMVB & $177(15)$ & $1007(85)$ & $1184(100)$ \\
OTMVB & $2(1)$ & $197(99)$ & $199(100)$ \\
\hline Totals & 179 & 1204 & 1383 \\
\hline
\end{tabular}

ITMVB: within the Trans-Mexican Volcanic Belt; OTMVB: outside of the Trans-Mexican Volcanic Belt. SiU: silica urolithiasis; OU: other urolithiasis.

mean of $16.4 \pm 7 \mathrm{mg} / \mathrm{L}$, and there were statistically significant differences between the regions $(p<0.0001)$.

In particular, for the two OTMVB areas, the concentration of $\mathrm{Si}$ in the water ranged from 3 to $30 \mathrm{mg} / \mathrm{l}$, with a mean of $18 \pm 8.2 \mathrm{mg} / \mathrm{L}$ in the north region, and ranged from 6 to $22 \mathrm{mg} / \mathrm{L}$, with a mean of $13.9 \pm 4 \mathrm{mg} / \mathrm{L}$ in the south region. There were no significant differences between these two geographic regions OTMVB $(p=0.64)$.

\section{Discussion}

The high frequency of SiU in dogs in Mexico, as well as in other animal and human populations in other parts of the world, might be associated with a geographic risk factor $[13,19]$. Given the 179 cases of $\mathrm{SiU}$ in Mexico, we were able to identify its geographical distribution [13]. We noted that $99 \%$ of cases were in ITMVB. This area is a chain of volcanoes that extends transversely from coast to coast, from the Revillagigedo Islands in the Pacific Ocean to the Gulf of Mexico [22]. In urolithforming dogs, living in this geographical area was a significant risk factor for forming $\mathrm{SiU}$.

Urinary supersaturation with this mineral is essential for the formation of uroliths; the excreted amount of $\mathrm{SiO}$ in the urine is proportional to the amount ingested in the diet from solid food and water [23]. Once ingested, $\mathrm{Si}$ is absorbed and reaches the blood plasma, passes to the tissues, and is excreted by the kidney through glomerular filtration, which is not reabsorbed by the tubules, and eliminated in the feces [24]. The urinary excretion of $\mathrm{Si}$ is in the form of orthosilicate, to be later transformed into silicon dioxide $\left(\mathrm{SiO}_{2}\right)$ when it comes into contact with acidic urine [25].

In solid food, $\mathrm{SiO}$ is found as colloid molecules of the type "colloidal silica." This is a polymeric species, with large, aggregated, and charged molecules, which have a low absorption in the gastrointestinal tract because the particles must be decomposed into a soluble monomer so that they can be absorbed; the rate of hydrolysis in the gastrointestinal tract is slow compared to the window of opportunity for absorption in the small intestine [26]. In certain grain and cereal products, there is a silicon fitolitic type, which is digested and is easily absorbed in the gastrointestinal tract, and several vegetables with less soluble $\mathrm{SiO}$ are used in pet foods such as corn gluten, wheat, or rice husk; this can interact with the concentrations of Si in the blood. In our study, it was not possible to identify an association between $\mathrm{SiU}$ and the type of food consumed by the dogs. Information about the diet consumed by the dogs was incomplete.

In water, Si particles are predominantly of monomeric species, such as orthosilicic acid $\left(\mathrm{H}_{4} \mathrm{SiO}_{4}\right)$ [27]; they are small molecules with a highly soluble neutral charge, presenting high gastrointestinal absorption, and are expelled rapidly in the urine [28]. The higher $\mathrm{Si}$ concentration in the tap water in the TMVB in Mexico is consistent with the concentrations of $\mathrm{Si}$ in water that are linked to the geological characteristics of the area. Water with a high concentration of $\mathrm{Si}$ has been found in the aquifers in volcanic areas. In this study, the majority of the dogs consumed tap water. Only one dog was provided bottled water exclusively, and another consumed both tap water and bottled water; both dogs lived in ITMVB. Although the dogs that consumed another source of water also developed $\mathrm{SiU}$, which may be related to the bottled water, they probably consumed a high concentration of $\mathrm{Si}$. One study analyzed bottled water consumption and observed that those containing high concentrations of $\mathrm{Si}$ came from volcanic zones [29]; therefore, it is possible that bottled water consumed by these dogs was packaged within the same region.

With these findings, we observed that stone-forming dogs living within ITMVB have a higher risk of developing 


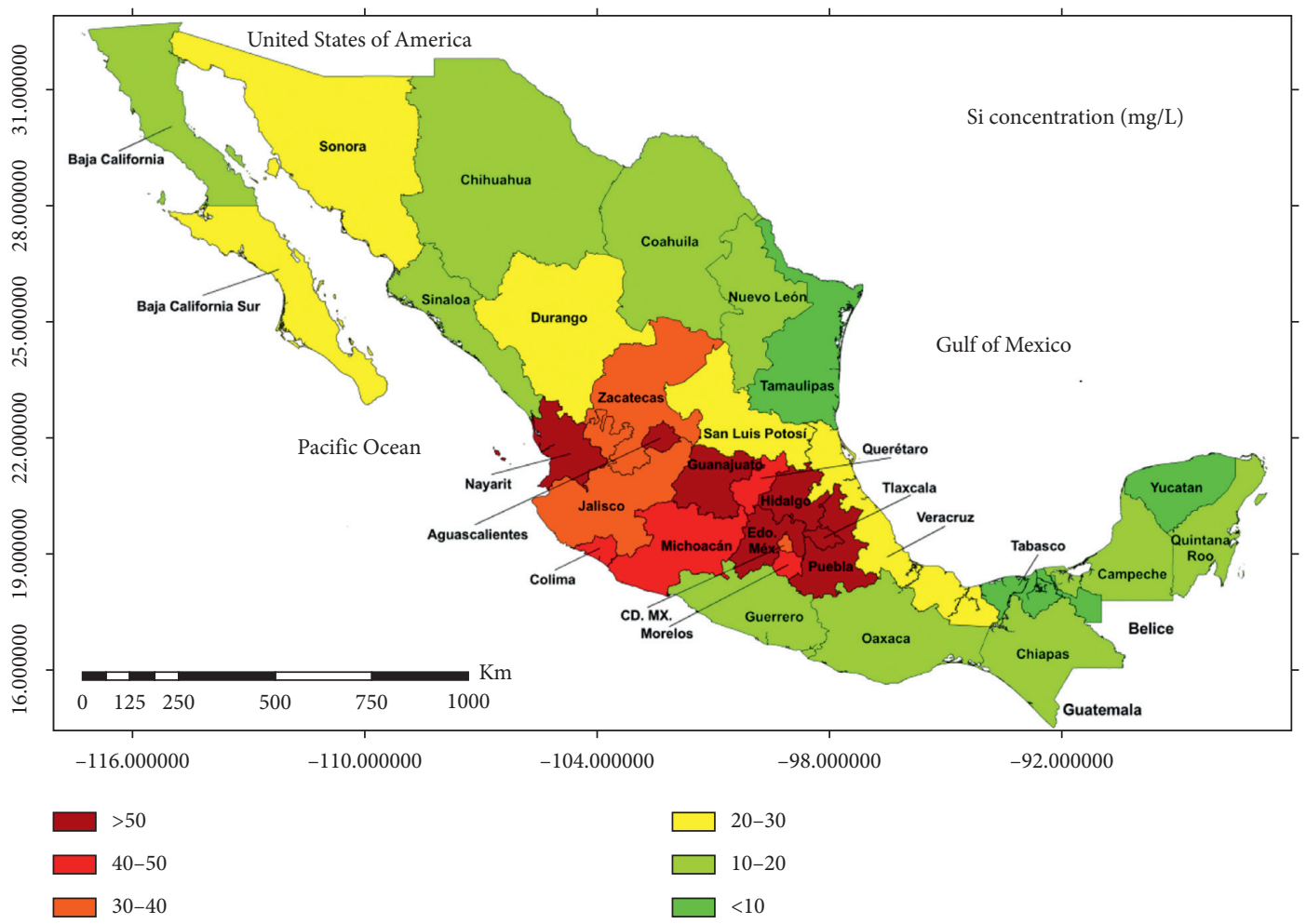

Figure 1: Mexican states with cases of $\mathrm{SiU}$ and regions with higher concentrations of Si in tap water.

TABle 3: Number of tap water samples analyzed by Mexican states, including the mean values, standard deviations, and range of Si concentration according to the state.

\begin{tabular}{|c|c|c|c|c|c|c|c|c|c|}
\hline \multirow{2}{*}{ State ITMVB } & \multicolumn{4}{|c|}{ Si concentration $(\mathrm{mg} / \mathrm{L})$} & \multirow{2}{*}{ State OTMVB } & \multicolumn{4}{|c|}{ Si concentration $(\mathrm{mg} / \mathrm{L})$} \\
\hline & $\mathrm{n}$ & Mean & $\mathrm{SD}$ & Range & & $\mathrm{n}$ & Mean & $\mathrm{SD}$ & Range \\
\hline Aguascalientes & 4 & 67.5 & 6.9 & $59-76$ & Baja California S & 3 & 28.7 & 0.5 & $28-29$ \\
\hline Mexico City & 5 & 38.6 & 2.4 & $36-42$ & Baja California $\mathrm{N}$ & 4 & 12 & 9.3 & $7-26$ \\
\hline Colima & 3 & 42 & 13.4 & $27-53$ & Campeche & 4 & 16 & 1.8 & $14-18$ \\
\hline Mexico state & 17 & 58.5 & 1.8 & $42-76$ & Chiapas & 4 & 13.2 & 4.0 & $10-19$ \\
\hline Guanajuato & 5 & 53.4 & 6.1 & $47-63$ & Chihuahua & 9 & 18.4 & 4.3 & $11-27$ \\
\hline Hidalgo & 6 & 65.5 & 3.3 & $62-73$ & Coahuila & 3 & 10.6 & 3.0 & $8-14$ \\
\hline Jalisco & 8 & 36.7 & 0.5 & $34-40$ & Durango & 2 & 29.5 & 0.7 & $29-30$ \\
\hline Morelos & 3 & 41.6 & 4.0 & $38-46$ & Guerrero & 6 & 14.4 & 5.2 & $6-20$ \\
\hline Michoacan & 5 & 48.2 & 5.8 & $43-55$ & Nuevo Leon & 5 & 9.4 & 2.19 & $8-13$ \\
\hline Nayarit & 5 & 67 & 9.8 & $52-76$ & Oaxaca & 4 & 19.7 & 4.5 & $13-22$ \\
\hline Puebla & 7 & 59.8 & 10.0 & $34-73$ & Quintana Roo & 6 & 16.7 & 7.0 & $6-22$ \\
\hline Queretaro & 6 & 45.5 & 9.1 & $37-61$ & San Luis Potosi & 4 & 20.5 & 2.1 & $10-29$ \\
\hline Tlaxcala & 3 & 55 & 2 & $53-57$ & Sinaloa & 5 & 16.2 & 1.7 & $14-19$ \\
\hline Veracruz & 8 & 29.4 & 2.5 & $27-34$ & Sonora & 5 & 27.6 & 1.6 & $25-29$ \\
\hline \multirow[t]{3}{*}{ Zacatecas } & 3 & 40 & 1 & $39-41$ & Tabasco & 5 & 8 & 2 & $6-10$ \\
\hline & & & & & Tamaulipas & 4 & 7.7 & 3.3 & $3-10$ \\
\hline & & & & & Yucatán & 7 & 9.6 & 3.2 & $7-15$ \\
\hline
\end{tabular}

ITMVB: within the Trans-Mexican Volcanic Belt; OTMVB: outside of the Trans-Mexican Volcanic Belt.

$\mathrm{SiU}$ because the drinking water of this region contains a higher concentration of $\mathrm{Si}$ (Figure 1). In humans, the frequency of $\mathrm{SiU}$ is unknown because conventional techniques, such as the metabolic profile of lithiasis performed in humans, do not allow the identification of this mineral [30] and for the identification of $\mathrm{SiO}$ in uroliths, it is necessary to use analysis techniques, such as infrared spectroscopy. The cases of $\mathrm{SiU}$ in the dogs studied herein can be a sentinel 


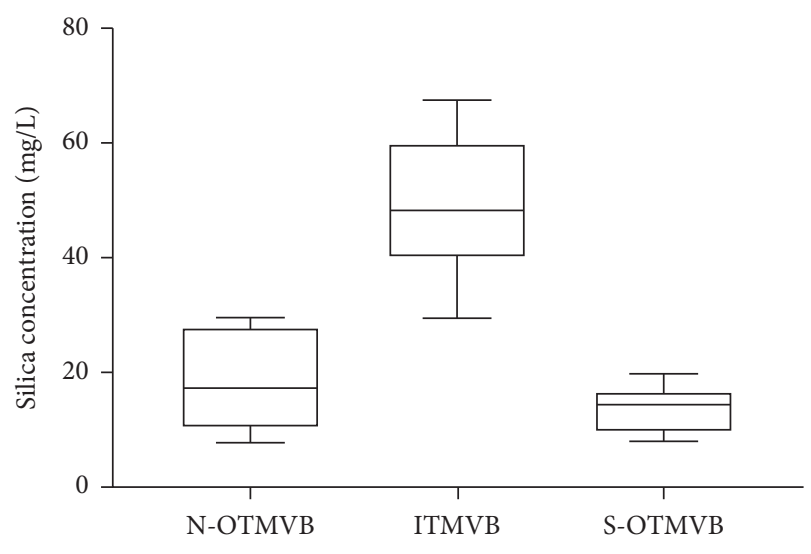

FIGURE 2: Mean values and standard deviation of the concentration of $\mathrm{Si}$ in the tap water of different geographical areas. N-OTMVB: north region outside of the Trans-Mexican Volcanic Belt; ITMVB: within the Trans-Mexican Volcanic Belt; and S-OTMVB: south region outside of the Trans-Mexican Volcanic Belt.

epidemiological model for the presentation of urolithiasis in humans in Mexico.

\section{Conclusions}

From these epidemiological data, we conclude that dogs living in the Trans-Mexican Volcanic Belt of Mexico have a higher risk of forming silica uroliths because of the high concentrations of $\mathrm{Si}$ in the water in this area. Other sources of silica such as local vegetation, dirt, and air are also potential sources of silica, but were not tested in our study.

\section{Limitations}

For the study period, it was not possible to obtain exclusive water samples from the patient with urolithiasis and data such as volume or frequency of ingestion of tap water and factors that together with the high concentrations of silica in tap drinking water can influence the development of SiU.

\section{Data Availability}

The data used to support the findings of this study are available from the corresponding author upon request via email,dlangel@uaemex.mx.

\section{Conflicts of Interest}

The authors declare no conflicts of interest.

\section{Acknowledgments}

Claudia Iveth Mendoza-López and María Alejandra AkéChiñas were $\mathrm{PhD}$ students with a scholarship of the Mexican Consejo Nacional de Ciencia y Tecnología (CONACyT).

\section{References}

[1] J. P. Lulich, C. A. Osborne, H. Albasan, L. A. Koehler, and L. M. Ulrich, "Recent shifts in the global proportions of canine uroliths," Veterinary Record, vol. 6, no. 172, pp. 363-370, 2013.

[2] M. K. Oyafuso, M. M. Kogika, M. F. Waki, C. S. Prosser, C. Z. Cavalcante, and V. A. B. F. Wirthl, "Urolitíase em cães: avaliação quantitativa da composição mineral de 156 urólitos," Ciência Rural, vol. 40, no. 1, pp. 102-108, 2010.

[3] D. Vrabelova, P. Silvestrini, J. Ciudad et al., "Analysis of 2735 canine uroliths in Spain and Portugal. A retrospective study: 2004-2006," Research in Veterinary Science, vol. 91, no. 2, pp. 208-211, 2011.

[4] K. Roe, A. Pratt, J. Lulich, C. Osborne, and H. M. Syme, "Analysis of 14,008 uroliths from dogs in the UK over a 10year period," Journal of Small Animal Practice, vol. 53, no. 11, pp. 634-640, 2012.

[5] D. M. Houston, H. E. Weese, N. P. Vanstone et al., "Analysis of canine urolith submissions to the Canadian Veterinary Urolith Centre, 1998-2014," Canadian Veterinary Journal, vol. 58, no. 1, pp. 45-50, 2017.

[6] B. R. Jones, A. J. Omodo-Eluk, H. Larkin, K. D. Rogers, and M. Sperrin, "Canine uroliths: analysis of uroliths from dogs in Ireland," Irish Veterinary Journal, vol. 54, no. 12, pp. 629-632, 2001.

[7] A. Blavier, A. Sulter, A. Bogey, K. Novelli, and B. Billiemaz, "Résultats des analyses par spectrométrie infrarouge de 1131 calculs urinaires canins prélevés de 2007 à 2010, en France," Pratique Médicale et Chirurgicale de l'Animal de Compagnie, vol. 47, no. 1, pp. 7-16, 2012.

[8] B. Bende, K. B. Kovács, N. Solymosi, and T. Németh, "Characteristics of urolithiasis in the dog population of Hungary from 2001 to 2012," Acta Veterinaria Hungarica, vol. 63, no. 3, pp. 323-336, 2015.

[9] W. W. Low, J. M. Uhl, P. H. Kass, A. L. Ruby, and J. L. Westropp, "Evaluation of trends in urolith composition and characteristics of dogs with urolithiasis: 25,499 cases (1985-2006)," Journal of the American Veterinary Medical Association, vol. 236, no. 2, pp. 193-200, 2010.

[10] F. Brandenberger-Schenk, E. Rothenanger, C. E. Reusch, and B. Gerber, "Uroliths of dogs in Switzerland from 2003 to 2009," Schweizer Archiv für Tierheilkunde, vol. 157, no. 1, pp. 41-48, 2015.

[11] J. Del Angel-Caraza, I. Diez-Prieto, C. C. Pérez-García, and M. B. García-Rodríguez, "Composition of lower urinary tract stones in canines in Mexico city," Urological Research, vol. 38, no. 3, pp. 201-204, 2010.

[12] C. I. Mendoza-López, J. Del-Angel-Caraza, M. A. Aké-Chiñas et al., "Epidemiology of urolithiasis in dogs from Guadalajara city, Mexico," Veterinaria Mexico OA, vol. 6, no. 1, pp. 1-14, 2019.

[13] C. I. Mendoza-López, J. Del-Angel-Caraza, M. A. Aké-Chiñas, I. A. Quijano-Hernández, and M. A. Barbosa-Mireles, "Canine silica urolithiasis in Mexico (2005-2018)," Veterinary Medicine International, vol. 2020, Article ID 8883487, 7 pages, 2020.

[14] C. B. Bailey, "Silica metabolism and silica urolithiasis in ruminants: a review," Canadian Journal of Animal Science, vol. 61, no. 2, pp. 219-235, 1981.

[15] C. A. Osborne, F. Jacob, J. P. Lulich et al., "Canine silica urolithiasis," Veterinary Clinics of North America: Small Animal Practice, vol. 29, no. 1, pp. 213-230, 1999.

[16] R. S. Brodey, R. Thomson, P. Sayer, and B. Eugster, "Silicate renal calculi in Kenyan dogs," Journal of Small Animal Practice, vol. 18, no. 8, pp. 523-528, 1977. 
[17] N. A. Cruz-Guerra, M. A. Gómez-García, F. Lovaco-Castellano et al., "Silica urolithiasis: report of a new case," Actas Urologicas Españolas, vol. 24, no. 2, pp. 405-407, 2000.

[18] N. Toshiyuki, E. Shin-Ichi, E. Hideki et al., "Renal silica calculi in an infant," International Journal of Urology, vol. 11, no. 2, pp. 119-121, 2004.

[19] A. Dessombz, B. Kirakoya, G. Coulibaly et al., "High prevalence of opaline silica in urinary stones from Burkina Faso," Urology, vol. 86, no. 6, pp. 1090-1096, 2015.

[20] L. Ferrari, T. Orozco-Esquivel, V. Manea, and M. Manea, "The dynamic history of the Trans-Mexican volcanic belt and the Mexico subduction zone," Tectonophysics, vol. 522-523, pp. 122-149, 2012.

[21] E. W. Rice, R. B. Baird, and A. D. Eaton, Standard Methods for the Examination of Water and Wastewater, American Public Health Association, American Water Works Association, Water Environment Federation, Washington, DC, USA, 23rd edition, 2017.

[22] A. Gómez-Tuena, M. T. Orozco-Esquivel, and L. Ferrari, "Igneous petrogenesis of the transmexican volcanic Belt," Geology of Mexico: Celebrating the Centenary of the Geological Society of Mexico, Geological Society of America, vol. 422, Boulder, CO, USA, 2007.

[23] R. Jugdaohsingh, S. H. Anderson, K. L. Tucker et al., "Dietary silicon intake and absorption," The American Journal of Clinical Nutrition, vol. 75, no. 5, pp. 887-893, 2002.

[24] J. A. T. Pennington, "Silicon in foods and diets," Food Additives and Contaminants, vol. 8, no. 1, pp. 97-118, 1991.

[25] A. J. Adler and G. M. Berlyne, "Silicon metabolism II. Renal handling in chronic renal failure patients," Nephron, vol. 44, no. 1, pp. 36-39, 1986.

[26] K. Van Dyck, R. Van Cauwenbergh, H. Robberecht, and H. Deelstra, "Bioavailability of silicon from food and food supplements," Fresenius' Journal of Analytical Chemistry, vol. 363, no. 5-6, pp. 541-544, 1999.

[27] S. Sripanyakorn, R. Jugdaohsingh, H. Elliott et al., "The silicon content of beer and its bioavailability in healthy volunteers," British Journal of Nutrition, vol. 91, no. 3, pp. 403-409, 2004.

[28] D. M. Reffitt, R. Jugdaohsingh, R. P. H. Thompson, and J. J. Powell, "Silicic acid: its gastrointestinal uptake and urinary excretion in man and effects on aluminium excretion," Journal of Inorganic Biochemistry, vol. 76, no. 2, pp. 141-147, 1999.

[29] S. Giammarioli, M. Mosca, and E. Sanzini, "Silicon content of Italian mineral waters and its contribution to daily intake," Journal of Food Science, vol. 70, no. 8, pp. s509-s512, 2005.

[30] S. Gràcia-Garcia, F. Millán-Rodríguez, F. Rousaud-Barón et al., "Why and how we must analyze urinary calculi," Actas Urológicas Españolas (English Edition), vol. 35, no. 6, pp. 354-362, 2011. 